\title{
浸水した大規模地下駐車場からの 避難に関する検討
}

\author{
高橋 祐樹 1 - 石垣 泰輔 2 - 馬場 康之 3 ・ 戸田 圭一 4 \\ 1正会員 中央コンサルタンツ株式会社 名古屋支店 水環境部（干451-0042 名古屋市西区那古野2-11-23） \\ E-mail: yuk-takahashi@chuoh-c.co.jp \\ 2正会員 関西大学教授 環境都市工学部都市システム工学科（†564-8680 吹田市山手町3-3-35） \\ E-mail: ishigaki@kansai-u.ac.jp \\ 3正会員 京都大学准教授 防災研究所（干611-0011 宇治市五ヶ庄） \\ 4正会員 京都大学教授 大学院工学研究科 社会基盤工学専攻（干615-8540 京都市西京区京都大学桂）
}

\begin{abstract}
近年, 都市部において $50 \mathrm{~mm} / \mathrm{h}$ 以上の集中豪雨によって，地下空間に雨水が流れ込む場合がある. 車が水 没する地下空間は, アンダーパスだけでなく地下駐車場もあることから, 本研究では, 浸水した地下駐車 場で車が水没した場合, 水深が何mになるまでに車外へ脱出する必要があるかを調べた. また, 構造格子 モデルを用いた浸水解析，実験結果を用いた地下駐車場からの避難解析を併用することで，地下駐車場か らの避難開始の遅れが避難の安全性にどのような影響を与えるのかを検討した. 実験結果から, セダン車 での脱出限界水深を得ることができ, 解析結果から, 水没車に閉じ込められた場合, 避難開始の遅れが避 難の安全性に大きく影響することや，駐車場の階層による危険度の違い，成人男性と高齢者女性による危 険度の違いなどを定量的に確認できた。
\end{abstract}

Key Words : underground parking lot, submerged car, evacuation, experiment, flood simulation

\section{1. はじめに}

近年, 地球規模の気候変動に伴う局所的な集中豪雨の 増加が問題となっている. 都市部では $50 \mathrm{~mm} / \mathrm{h}$ 以上の激 しい集中豪雨によって, 地下空間に雨水が流れ込む場合 がある. 実際に 2008 年 8 月 27 日には杤木県鹿沼市の東 北自動車道下が冠水し, 人が自動車に閉じ込められると いう被害が生じた. $50 \mathrm{~mm} / \mathrm{h}$ 以上の降雨の増加は，この ような都市水害発生の増加の可能性もはらんでいる. 都 市水害発生の要因は降雨だけではない. 都市化というの も要因の 1 つである. 日本の都市化の進展は経済成長に 大きく貢献したと同時に, 地表面を浸透能力の少ないア スファルトやコンクリートで覆っていった．そのため, 降った雨は速やかに雨水排水施設に集まるようになり, その排水能力を超える激しい雨が降った場合, 内水汇濫 の被害が生じるようになった. 特に都市部では限られた 土地を有効利用するために地下構造物が多く存在する. 例えば，大阪梅田には，広大な地下街が広がっており， また，地下駐車場というような施設を備えている，JR 大阪駅の南側だけで, 10 箇所を超える地下駐車場があり, 自動車の駐車可能台数としては 2000 台を超える. ひと
たび地上が汇濫すると汇濫水が浸入し甚大な被害が生 じると考えられる.

そこで本研究では, 浸水した地下駐車場で車が水没し た場合, 水深が何 $m$ になるまでに車外一脱出する必要 があるかを調べた。既報 ${ }^{1}$ では単層の地下駐車場におけ る浸水状況と成人男性を対象とした避難に関寸る検討 を, 構造格子モデルを用いた浸水解析, 実験結果を用い た地下駐車場からの避難解析を併用することで, 水没車 から脱出し, 浸水した地下駐車場から地上一避難できる のか, 地下駐車場からの避難開始の遅れが地上までの避 難の安全にどのような影響を与えるのかについて検討 した. 本論文では, 既報での検討に加え, 地下駐車場の 階層による浸水危険性の違い, および成人男性のみなら ず高齢者女性の避難時危険性についても検討を加える とともに, 適切な情報がアナウンスされた場合の効果に ついて考察を行っている.

\section{2. 水没車を用いた脱出実験について}

地下駐車場が浸水した場合，早期の避難が必要である が，早期避難ができずに水没した車から避難する場合， 


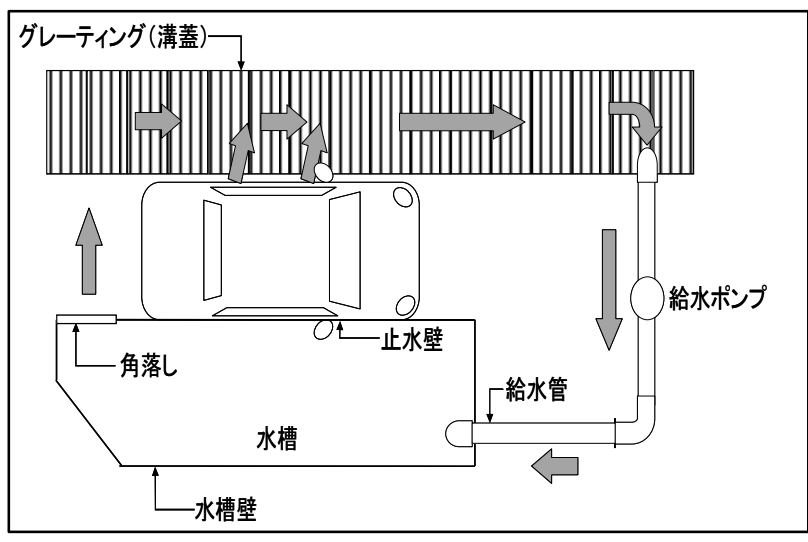

図-1 実験装置の概要図 ${ }^{4)}$

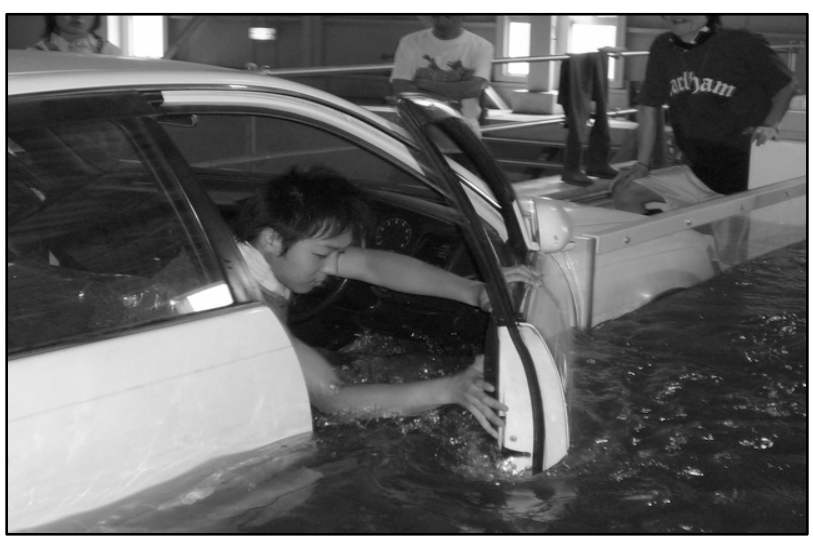

写真-1 脱出実験の様子

1) 避難の必要性を認知する,

2) 車から脱出する,

3）浸水したフロアおよび階段を通って地上に避難す る,

という行動パターンをとる.この一連の行動については, 避難の必要性を認知できるか，水圧が作用したドアを開 閉できるのか，浸水したフロアおよび階段を安全に歩行 できるのかが避難の成功の条件となる，これまで，著者 らは浸水時の歩行避難 $\left.{ }^{2)}, 3\right)$ ，および水没した実車からの 避難実験4),5)，6)を行ってきた。本研究ではこれらの研究 結果および追加実験の結果を用いており，浸水した地下 駐車場からの避難限界を判定するとともに，脱出可能な 条件下における浸水深ごとのドア開閉時間を算定してい る.これらの算定には, 既報の成果を利用しているため, ここでは，実験およびその結果の概要を説明したのち， 3.の避難に関する検討との関係について述べる.

\section{（1）水没車からの脱出実験}

\section{a) 実験装置と実験方法}

京都大学防災研究所宇治川オープンラボラトリー内 に設置されている実物大のセダン車模型を用いた. 実験 装置の概要を図-1に示す。車模型は, 床面に固定されて おり, 床面からドア下端まで $0.31 \mathrm{~m}$ となっている. 水槽

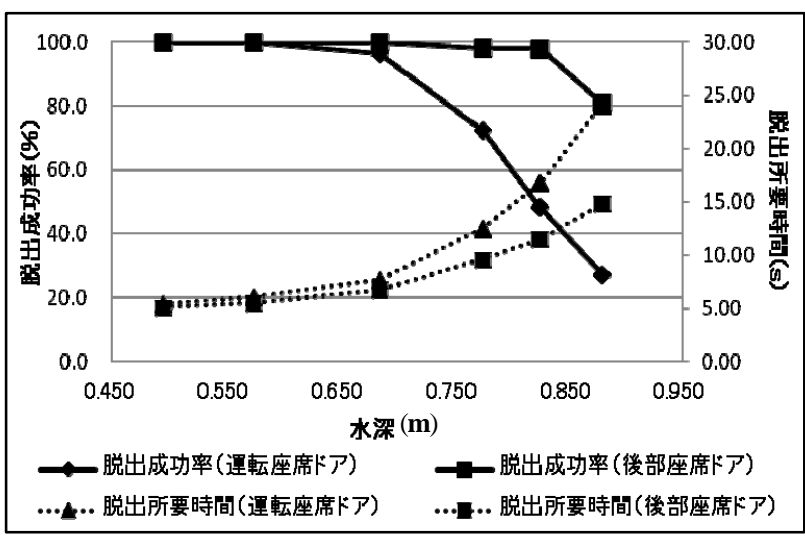

図-2 成人男性の脱出成功率と脱出所要時間の結果 ${ }^{4)}$

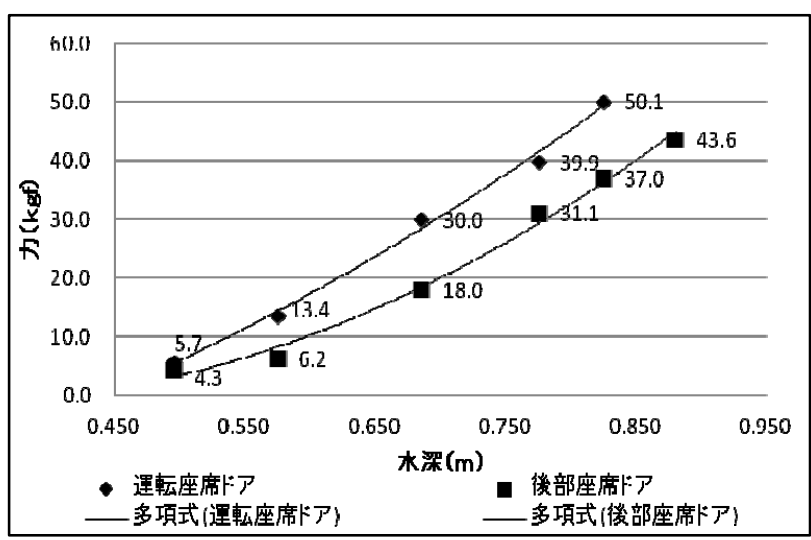

図-3 ドアを開けるのに必要な力の結果 ${ }^{4)}$

内の水深は，床面から最大 $1 \mathrm{~m}$ までの間を設定でき，角 落としの高さを変化させることで調節が可能であり, 角 落としから越流した水はグレーティングの下を流れ, 給 水ポンプにより再び水槽に循環する仕組みになってい る. 常に水が循環されるので, ドア開閉時の水深条件の 変動を最小限に抑えて, 可能な範囲で一定に近い条件下 での実験が可能である.

被験者は，各水深において運転座席ドアおよび後部座 席ドアから脱出を行い, その成否およびドアを開けて車 外へ脱出するまでの所要時間を測定した. 被験者は, 前 後のドアにおいて一度脱出に失敗すると, 次の段階の水 深に挑戦することはできないこととした．水深条件は， $0.495 \mathrm{~m}, 0.575 \mathrm{~m}, 0.685 \mathrm{~m}, 0.775 \mathrm{~m}, 0.825 \mathrm{~m}, 0.880 \mathrm{~m}$ と した. 脱出実験の様子を写真-1 に示寸. 被験者のうち, 男性が 59 名と全体の 9 割以上を占めているので，以下 では成人男性の結果で考察する.

\section{b) 実験結果}

成人男性の脱出成功率と脱出所要時間との関係を図 -2 に示す. 脱出成功率は, 水深 $0.575 \mathrm{~m}$ までは, 運転座 席と後部座席で, 全ての被験者が脱出できたという結果 になった. しかし, 運転座席は水深が $0.685 \mathrm{~m}$ になると 成功率が 96.4\%になり, それ以降, 成功率が急激に減少 する. 後部座席では, 運転座席ほどの急激な変化はなく, 


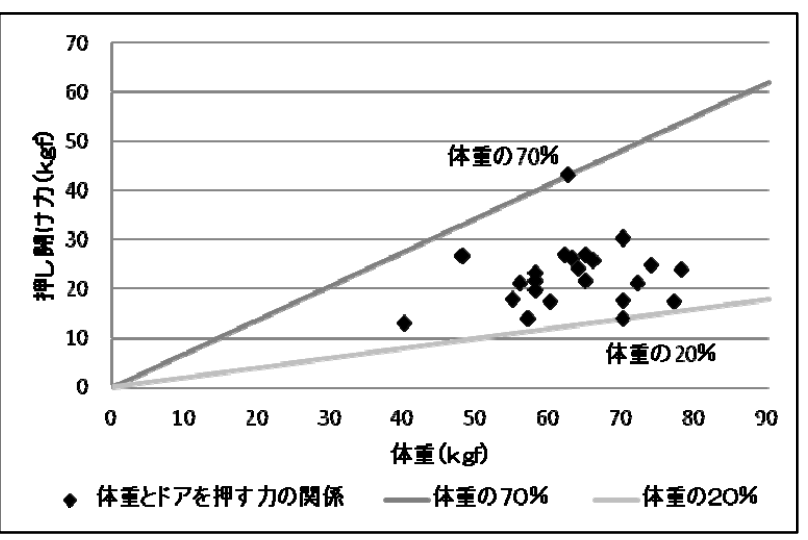

図-4 成人男性の体重とドアを押す力の結果 ${ }^{4)}$

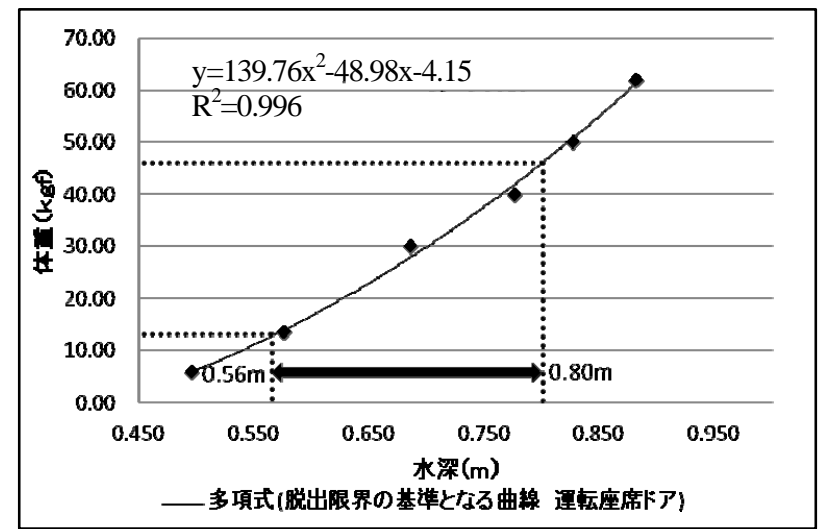

図-5 成人男性の脱出限界水深の算出方法

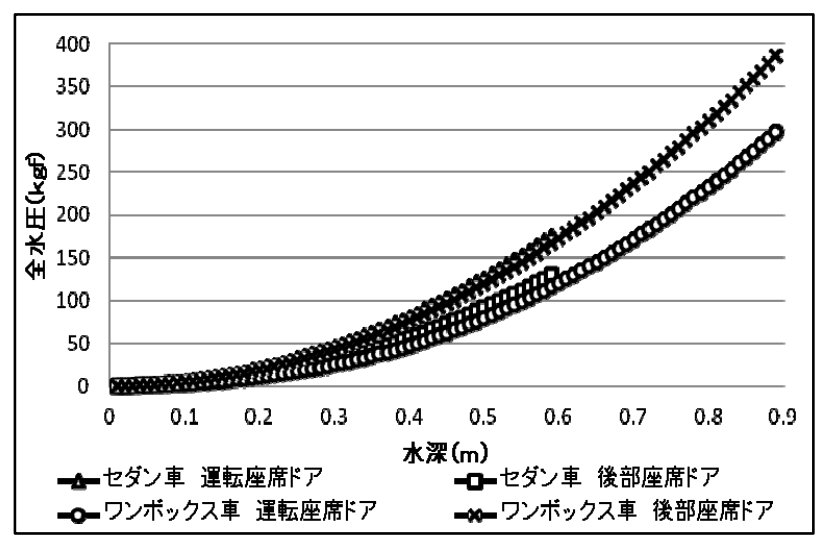

図-6 ドア下端から測った水深と全水圧

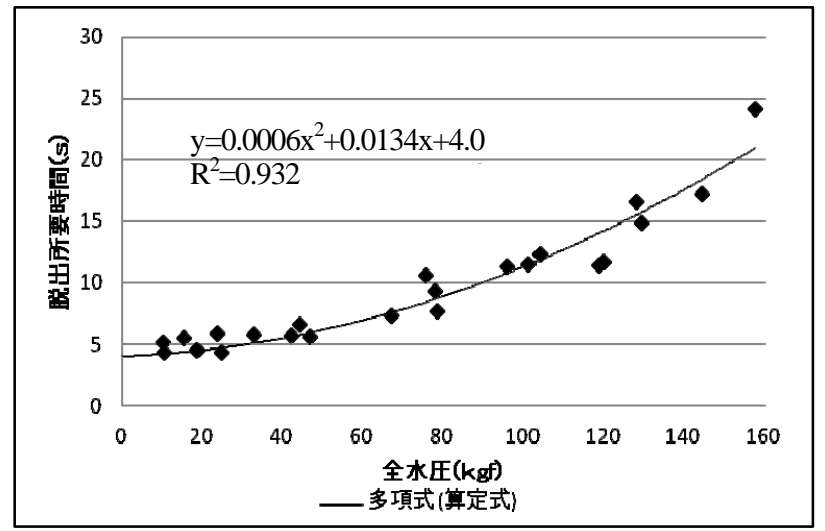

図-7 成人男性の脱出所要時間の算定式
水深が $0.825 \mathrm{~m}$ で $90 \%$ 以上の被験者が脱出でき，水深 0.880m でも 80\%ほどの被験者が脱出できるという結果 となった. 脱出所要時間については, 運転座席ドアと後 部座席ドアの両方で, 水深が上昇するにつれ脱出所要時 間が長くなる結果となった. 1 前の水深と比べた所要 時間の増加量は水深が深くなるごとに大きくなってい る.

\section{（2）ドアを開けるのに必要な力の計測実験}

\section{a) 実験方法}

測定にはロードセルを用いた. ロードセルからの出力 電圧は $10 \mathrm{~Hz}$ で 60 秒間計測し，事前に検定された出力電 圧と力の関係により変換している。 この実験を始める前 にロードセルに, 0kgf, 10kgf, 20kgf, 30kgf, 40kgf, 50kgf, $60 \mathrm{kgf}$ の荷重をかけて出力電圧と力の関係を求めた.

b) 実験結果

水深とドアを開けるのに必要な力の関係を図-3に示 す. 水深が深くなるにつれてドアを開けるのに必要な力 が大きくなっていくことがわかる. 運転座席ドアを開け るのに必要な力に比へ，水圧の作用寸る面積が少ない後 部座席ドアを開けるのに必要な力の方が小さいという こともわかった。
（3）体重とドアを押すカの関係を求める実験

a) 実験方法

ドアを開けるのに必要な力と比較・検討を行うために, ここでは，ロードセルを用い，自動車内に座ったときの 右手側にあるドアを押す力を計測した.

\section{b) 実験結果}

体重とドアを押寸力の関係を図-4 に示す. 縦軸にドア を押す力をとったグラフに被験者 34 名のデータを記入 したものである. 実験結果の分布から, 成人男性は, 体 重の $20 \%$ 70\%に当たるドアを押す力があることがわ かった.

\section{（4） 水没車からの脱出限界水深と脱出所要時間}

脱出限界を求める過程を図-5 に示寸. 平成 20 年度体 力・運動能力調查 》によると, 成人男性の平均体重は 65kgf であると定義されている. 実験結果より, 成人男 性には体重の 20\%〜70\%に当たるドアを押寸力がある ことがわかったので, 成人男性のドアを押寸力は $13 \mathrm{kgf}$ 〜46kgf と求められる. この值を, ドアを開けるのに必 要な力の計測で求めた水深と力の関係の曲線に代入す ると, $0.56 \mathrm{~m} \sim 0.80 \mathrm{~m}$ となり, 安全側で見て, 脱出限界 水深 $0.56 \mathrm{~m}$ とした. またこの $0.56 \mathrm{~m}$ と脱出実験で得ら 

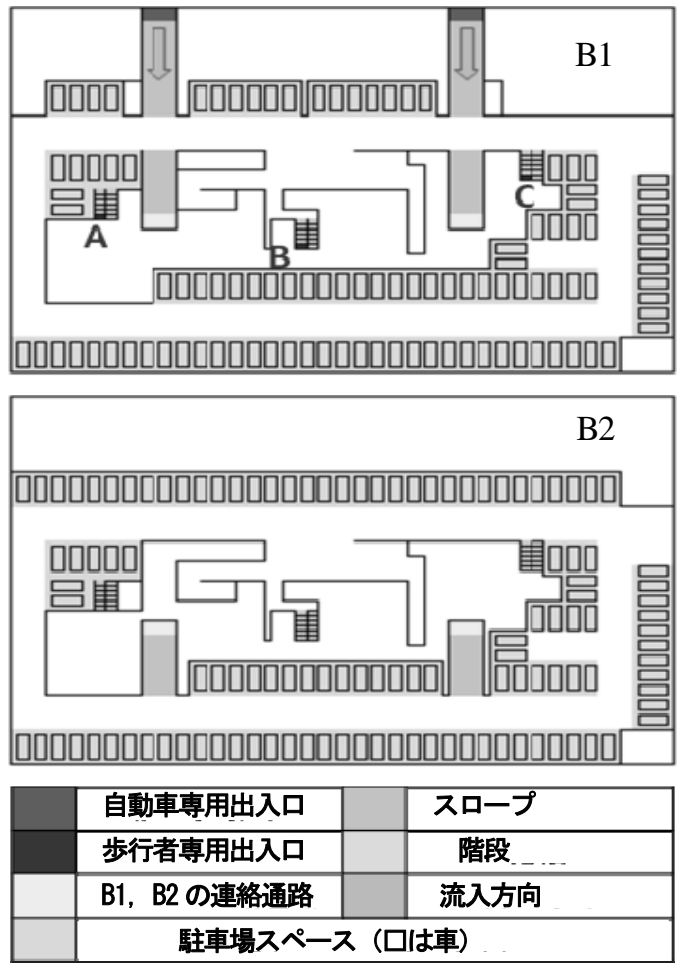

図-8＼cjkstart解析対象とした 2 層構造地下駐車場

れた脱出成功率の結果を比較しても, 運転座席ドアおよ び後部座席ドアの脱出成功率が 100\%を満たしているこ とから，0.56m は適当な值であると言える. よって，避 難解析には $0.56 \mathrm{~m}$ を用いた.

脱出所要時間に関しては，ドアにかかる全水圧を用い て算出する. セダン車と既報の研究 ${ }^{8)}$ で行われたワンボ ックス車それぞれの運転席ドア及び後部座席ドアは，4 つともドアの形状が異なる，そこで，それぞれのドア前 の水深と全水圧の関係を求めた. 各ドアのドア前の水深 と全水圧の関係を図-6に示寸. セダン車とワンボックス 車それぞれの運転席ドア及び後部座席ドアからの脱出 実験によって得られた水深ごとの脱出所要時間 (成人男 性 40 名）を全水圧に置き換えた，その結果を図-7 に示 す. 各ドアの結果はほぼ同様な值, 増加量であるので, それぞれのデータを 1 つのデータとし，そこから近似式 を導き, その式から脱出所要時間を求めて避難解析に反 映した. ドアに水圧がかかっていない場合の脱出所要時 間は，実験結果より，平均值が約 4 秒であったので，近 似式の切片を 4 秒と設定した.

\section{3. 地下駐車場からの避難に関する検討}

ここでは, 脱出実験で得られた脱出限界水深と脱出所 要時間を用いた避難解析を行い, 水没車からの脱出を考 慮した地下駐車場からの浸水時避難に関して検討する。

\section{(1) 浸水解析}

\section{a) 浸水解析モデル}

本研究では, 計算対象領域を正方形の格子に分割して 計算する構造格子モデルを用いた. 分割格子は一辺 $1 \mathrm{~m}$ の正方形格子を用いた．浸水解析の手法は, 以下の浅水 方程式を基礎式とした武田 ${ }^{99}$ の研究の手法を用いた. 連続式

$$
\frac{\partial h}{\partial t}+\frac{\partial M}{\partial x}+\frac{\partial N}{\partial y}=0
$$

運動量式

$x$ 方向

$$
\frac{\partial M}{\partial t}+\frac{\partial(u M)}{\partial x}+\frac{\partial(v M)}{\partial y}=-g h \frac{\partial H}{\partial x}-\frac{\tau_{b x}}{\rho}
$$

$y$ 方向

$$
\frac{\partial N}{\partial t}+\frac{\partial(u N)}{\partial x}+\frac{\partial(v N)}{\partial y}=-g h \frac{\partial H}{\partial y}-\frac{\tau_{b y}}{\rho}
$$

ここに, $h$ は水深, $u, v$ は $x, y$ 方向の流速, $M, N$ は $x$, $y$ 方向の流量フラックス $(M=u h, N=v h), H$ は水位 $(H=h+z$, $z$ は地盤高)， $\tau_{b x}, \tau_{b y}$ は水底面でのせん断応力成分の $x$, $y$ 方向成分である.

\section{b) 解析対象地}

$\mathrm{JR}$ 大阪駅南側にある地下駐車場を選定し，仮想地下 駐車場を作成した，その図を図-8 に示寸．形状は，縦 $88 \mathrm{~m}$, 横 $122 \mathrm{~m}$ の地下 2 層構造の地下駐車場である. 地 下 1 階, 地下 2 階の駐車台数は 105 台, 117 台である. 直上階は，地上 1 階である. 自動車専用出入口は， 1 階 が道路に繋がっており, 歩行者専用出入口は, 建物内部 に繋がっている. 粗度係数は, コンクリート構造なので, 0.015 と設定した. 地盤高は, 制限高さが $1.9 \mathrm{~m}$ の関係で, 地下 1 階の地盤高を $3 \mathrm{~m}$ とし, 地下 2 階の地盤高を $0 \mathrm{~m}$ と設定した. その際, 地下 1 階と地下 2 階に通ずる階段 についても考慮している. 地上出入口は3 箇所設けられ ており, 左から A，B，C と定義した。

\section{c) 自動車の形状と配置}

自動車の形状は, 既報の研究 ${ }^{8)}$ を参考に, 普通自動車 の平均的な大きさを用い, 全幅を $2 \mathrm{~m}$, 全長を $5 \mathrm{~m}$ とし た. 自動車の配置は, 駐車率を $50 \%$ と仮定した. よって, 地下 1 階, 地下 2 階合わせて 111 台の車が駐車している ものとした.

\section{d) 流入条件}

地下駐車場への流入は, 内水汇濫を想定し, 地上での 水深上昇速度 $0.02 \mathrm{~m} / \mathrm{min}$ とし ${ }^{10)}$, 段落ち式を用いて流量 を算定している. 地上から地下 1 階への流入箇所は, 自 動車専用出入口の 2 箇所とし, 非常階段 A，B，C から は流入しないものとした. 地下 1 階から地下 2 階へは, 2 箇所のスロープと非常階段 A，B，C から流れるもの 


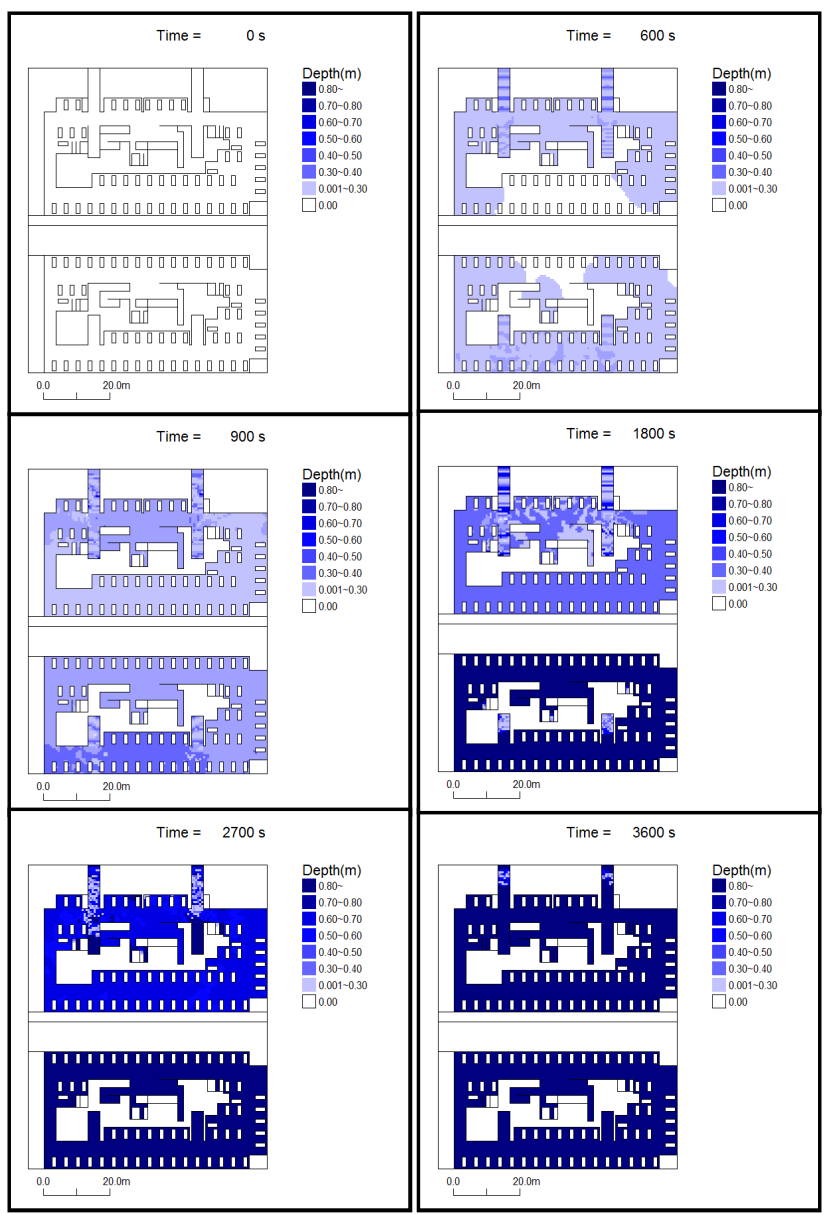

図-9２層構造地下駐車場の浸水解析結果

とした．流入開始は，時刻 0 秒から始め，解析時間は， 地下 1 階と地下 2 階の水深変化を得るため, 3600 秒とし た.

\section{（2）浸水解析結果}

浸水解析結果を図-9に示寸。対象地下駐車場の特徵と して，自動車専用出入口の向かい側にスロープが設置さ れているので，地下1階に流入する水の大半が，地下2階 一流れる. 寸なわち, 地下2階の水深上昇速度は, 地下 1 階よりも大きくなる結果となった.

\section{（3）避難解析}

\section{a) 単位幅比力の指標}

車から脱出し，浸水したフロアと階段を歩行避難する 際の危険度の評価は表-1に示寸大西ら ${ }^{2)}$ およびAsai et al. ${ }^{3)}$ の100名以上の体験者を対象とした研究で得られた単位 幅比力の指標を用いた．単位幅比力は，単位重量当たり の運動量と水圧の和である.ここに，流速 $(\mathrm{m} / \mathrm{s}) を u$, 水深 $(\mathrm{m})$ をhとしたとき, 単位幅比力 $M_{0}\left(\mathrm{~m}^{3} / \mathrm{m}\right)$ は $u^{2} h / g+h^{2} / 2$ の式で表され, 自力での安全な避難が困難にな る避難困難と, 避難行動がとれなくなる避難限界の值は, 表-1に示すとおりである.
表-1 単位幅比力 2),3)

\begin{tabular}{|c|c|c|}
\hline \multirow{2}{*}{ 被験者属性 } & \multicolumn{2}{|c|}{ 単䏠湢比力 } \\
\hline & 自力避難困難 & 自力避難限杲 \\
\hline 成人男性 & 0.125 & 0.250 \\
\hline 高齢男性 & 0.100 & 0.200 \\
\hline 成人女性 & 0.100 & 0.200 \\
\hline 高齢女怢 & 0.080 & 0.160 \\
\hline
\end{tabular}

表-2 歩行速度の低下率 ${ }^{3}$

\begin{tabular}{|c|c|c|}
\hline \multirow{2}{*}{ 破殹者属性 } & \multicolumn{2}{|c|}{ 歩行速度の墄少率の訪-算式 } \\
\hline & 通路部 & 階段部 \\
\hline 成人男性 & $V / N_{0}=0.45 \exp \left(-120 M_{0}\right)-0.85 M_{0}+0.55$ & $V / N_{0}=0.15 \exp \left(-100 M_{o}\right)-0.80 M_{0}+0.85$ \\
\hline 高齢男性 & $V / N_{0}=0.40 \exp \left(-120 M_{0}\right)-0.85 M_{0}+0.60$ & $V N_{0}=0.10 \exp \left(-25 M_{0}\right)-0.80 M_{0}+0.90$ \\
\hline 成人女性 & $V / N_{0}=0.60 \exp \left(-150 M_{0}\right)-0.50 M_{0}+0.40$ & $V N_{Q}=0.30 \exp \left(-60 M_{0}\right)-1.20 M_{0}+0.70$ \\
\hline 高齢女性 & $V N_{0}=0.55 \exp -125 M_{0}-0.45 M_{0}+0.45$ & $V N_{0}=0.15 \exp \left(-25 M_{0}\right)-1.40 M_{0}+0.70$ \\
\hline
\end{tabular}

表-3 シナリオ

\begin{tabular}{|c|c|}
\hline & 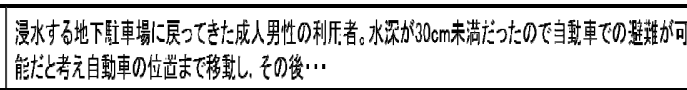 \\
\hline 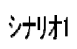 & 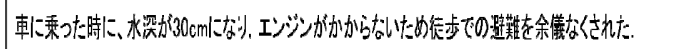 \\
\hline :シ十リt2 & 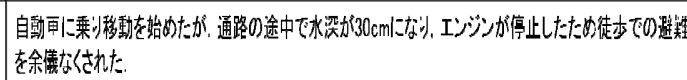 \\
\hline
\end{tabular}

\section{b) 浸水時の歩行速度}

浸水の歩行速度の評価は, 表-2に示寸Asai et al. ${ }^{3)}$ の研究 で得られた単位幅比力を用いた歩行速度の低下率の計算 式を用いた。ここに，Vは，その単位幅比力の歩行速度 $(\mathrm{m} / \mathrm{s}) ， V_{0}$ は非浸水時の歩行速度 $(\mathrm{m} / \mathrm{s}) ， M_{0}$ は単位幅 比力 $\left(\mathrm{m}^{3} / \mathrm{m}\right)$ である. 通路部の歩行速度減少率は地下駐 車場の平坦部分に適用し，歩行者専用出入口部分は階段 状であるため, 階段部分の歩行速度減少率を適用した. なお，成人男性 $V_{0}$ は，通路部 $1.4 \mathrm{~m} / \mathrm{s}$, 階段部 $0.7 \mathrm{~m} / \mathrm{s}$ とて いる.

c) 避難状況の想定

避難状況の想定は，水没車内からの脱出と駐車場外 の移動を想定した．解析においても駐車場外一の移動だ けでなく, 水没車からの脱出を含む避難の状況を想定し た. それを踏まえた 2つのシナリオを表-3に示す.なお， いずれのシナリオでも，地下駐車場で利用者が車に戻っ てきた時には水深が30cm未満であったという共通の条 件を前提としている. また，この30cmという水深では， 車のマフラーが床面から約0.30m付近にあるため, その 水深になった時にはマフラーが塞がれ, エンジンが停止 するものとして設定した值であり，車は浸水による浮力 を受けず，配置した位置から流されるなどの移動は考慮 しないものとした．シナリオ1では，駐車位置で水深 0.30mになり，車が動かなくなり，徒歩で避難を開始す 


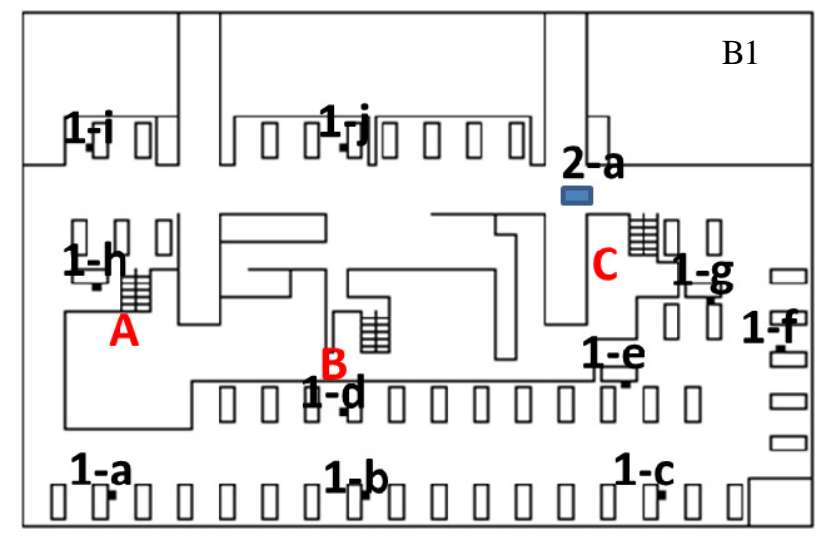

B2
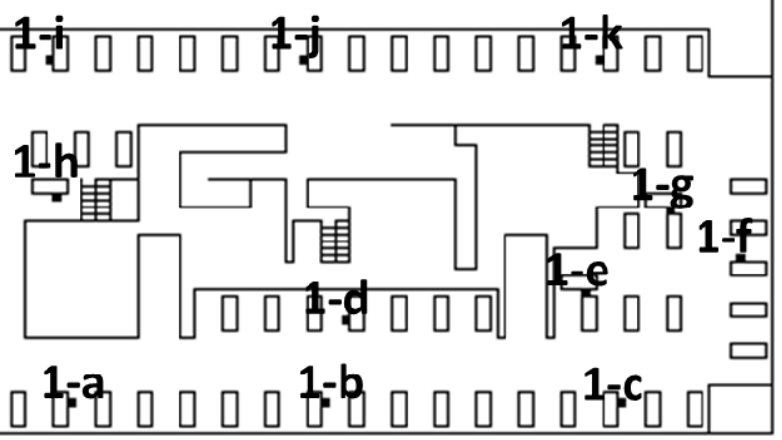

図-10 多層構造の各避難開始位置（シナリオ 1,2 )

るとした，その避難開始位置は，地下1階では1-a〜1-j, 地下2階では1-a〜1-kの計21箇所を選定した. シナリオ2 では，駐車位置での水深が $0.30 \mathrm{~m}$ 未満であったため自動 車専用出入口付近まで自動車で移動し，そこで水深 0.30mになり，徒歩での避難を開始するとした．その避 難開始位置を2-aの1箇所を選定した．地上への避難は， 水没車の運転座席から開始するものとした. シナリオ 1 , シナリオ2の各避難開始位置を図-10に示す. 避難経路は, 各避難開始位置と避難完了位置の2 点間を, あらかじめ最 短となる経路で結んだものとし, 自動車専用出入口から 駐車場外への移動は考えないこととした。避難完了位置 は, 各避難開始位置の最寄りの非常階段の最上段とした. 避難開始の遅れは地下1階ではそれぞれ0，60，120，180， 240，300，360秒と設定し，地下2階ではそれぞれ0，60， 120, 150, 180, 240, 270, 300,360秒とした.

\section{(4) 避難解析結果}

\section{a) 避難の成否}

以下の手順で，避難者を成人男性 1 名が，運転席ドア から脱出する場合について，避難の成否を判定した。

1）避難開始時の水深からアに作用する全水圧（図-6） を計算,

2) 全水圧からドア開屝可能性を判断,

3) 可能な場合, 脱出所要時間（図-7）を計算,

4) 表-2 を用いて浸水状況（浸水深，流速）を考慮した
表-4 成人男性の避難の成否（多層構造）

\begin{tabular}{|c|c|c|c|c|c|c|c|c|c|c|c|}
\hline \multicolumn{12}{|c|}{ 地下1嫱 } \\
\hline \multirow{2}{*}{ 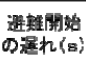 } & \multicolumn{11}{|c|}{ 各避雉位置からの避社の成否 } \\
\hline & 1.a & 1.b & $1 \cdot \mathrm{c}$ & 1.d & 1 1e & 1.f & 1.8 & 1.h & 1 1. & $1 \cdot j$ & 2.a \\
\hline 0 & 0 & 0 & 0 & 0 & 0 & 0 & 0 & 0 & 0 & 0 & 0 \\
\hline 60 & 0 & 0 & 0 & 0 & 0 & 0 & 0 & 0 & 0 & 0 & 0 \\
\hline 120 & 0 & 0 & 0 & 0 & 0 & 0 & 0 & 0 & 0 & 0 & 0 \\
\hline 180 & 0 & 0 & 0 & 0 & 0 & 0 & 0 & 0 & 0 & 0 & 0 \\
\hline 240 & 0 & 0 & 0 & 0 & 0 & 0 & 0 & 0 & 0 & 0 & 0 \\
\hline 300 & 0 & 0 & 0 & 0 & 0 & 0 & 0 & 0 & 0 & 0 & 0 \\
\hline 360 & 0 & 0 & 0 & 0 & 0 & 0 & 0 & 0 & 0 & 0 & 0 \\
\hline \multicolumn{12}{|c|}{ 地下2渚 } \\
\hline \multirow{2}{*}{ 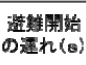 } & \multicolumn{11}{|c|}{ 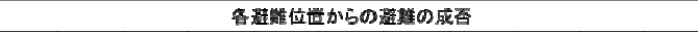 } \\
\hline & 1-a & $1-b$ & $1-c$ & 1-d & 1-e & \begin{tabular}{|l|}
$1-f$ \\
\end{tabular} & $1-\mathrm{g}$ & 1-h & $1-1$ & 1-J & $1-k$ \\
\hline 0 & 0 & 0 & 0 & 0 & 0 & 0 & 0 & 0 & 0 & 0 & 0 \\
\hline 60 & 0 & 0 & 0 & 0 & 0 & 0 & 0 & 0 & 0 & 0 & 0 \\
\hline 120 & $\Delta 0.03$ & 0 & $\Delta 0.36$ & 0 & $\Delta 0.32$ & 0 & 0 & 0 & 0 & 0 & 0 \\
\hline 150 & $\Delta 0.47$ & 0 & $\Delta 0.51$ & $\Delta 0.24$ & $\Delta 0.52$ & $\Delta 0.25$ & $\Delta 0.32$ & 0 & 0 & 0 & 0 \\
\hline 180 & $\Delta 0.70$ & 0 & $\Delta 0.76$ & $\Delta 0.39$ & $\Delta 0.64$ & $\Delta 0.69$ & $\Delta 0.59$ & $\Delta 0.07$ & $\Delta 0.14$ & $\Delta 0.30$ & 0 \\
\hline 240 & $\Delta 0.73$ & $\Delta 0.46$ & $x$ & $\Delta 0.80$ & $x$ & $\Delta 0.73$ & $\Delta 0.65$ & $\Delta 0.23$ & $\Delta 0.51$ & $\Delta 0.57$ & $\Delta 0.31$ \\
\hline 270 & $x$ & $\Delta 0.66$ & $x$ & $x$ & $x$ & $\Delta 0.76$ & $\mathrm{x}$ & $\Delta 0.24$ & $\Delta 0.53$ & $\Delta 0.58$ & $\Delta 0.33$ \\
\hline 300 & $x$ & $\Delta 0.71$ & $x$ & $x$ & $x$ & $x$ & $x$ & $\Delta 0.25$ & $\Delta 0.53$ & $\Delta 0.59$ & $\Delta 0.33$ \\
\hline 360 & $x$ & $x$ & $x$ & $x$ & $x$ & $x$ & $x$ & $x$ & $x$ & $x$ & $x$ \\
\hline
\end{tabular}

表-5 成人男性の避難所要時間（多層構造）

\begin{tabular}{|c|c|c|c|c|c|c|c|c|c|c|c|}
\hline \multicolumn{12}{|c|}{ 地下 1 階 } \\
\hline \multirow{2}{*}{$\begin{array}{l}\text { 避蜼開始 } \\
\text { 遮れ( } \\
\end{array}$} & \multicolumn{11}{|c|}{ 各避難位壴からの避難所要時間 (s) } \\
\hline & $1-\mathrm{a}$ & $1-b$ & $1-\mathrm{c}$ & 1-d & 1-e & $1-f$ & 1-g & 1-h & $1-\mathrm{i}$ & 1-j & 2-a \\
\hline 0 & 86 & 137 & 112 & 137 & 95 & 75 & 63 & 21 & 43 & 51 & 23 \\
\hline 60 & 88 & 139 & 112 & 139 & 96 & 75 & 63 & 22 & 43 & 51 & 23 \\
\hline 120 & 88 & 139 & 113 & 140 & 96 & 75 & 64 & 22 & 43 & 51 & 23 \\
\hline 180 & 88 & 139 & 114 & 141 & 97 & 77 & 65 & 22 & 43 & 52 & 25 \\
\hline 240 & 89 & 141 & 115 & 141 & 99 & 78 & 65 & 22 & 44 & 52 & 25 \\
\hline 300 & 89 & 142 & 116 & 143 & 100 & 79 & 65 & 22 & 44 & 54 & 25 \\
\hline 360 & 90 & 144 & 116 & 144 & 101 & 79 & 65 & 23 & 45 & 54 & 25 \\
\hline \multicolumn{12}{|c|}{ 地下2階 } \\
\hline \multirow{2}{*}{$\begin{array}{l}\text { 避蜼開始 } \\
\text { の遅れ九 (s) }\end{array}$} & \multicolumn{11}{|c|}{ 各避難位夏からの避難所要時間(s) } \\
\hline & 1-a & $1-b$ & $1-c$ & 1-d & 1-e & 1-f & 1-g & 1-h & $1-i$ & 1-j & $1-k$ \\
\hline 0 & 110 & 106 & 134 & 161 & 117 & 88 & 81 & 43 & 64 & 72 & 43 \\
\hline 60 & 113 & 108 & 140 & 166 & 121 & 92 & 86 & 45 & 67 & 75 & 44 \\
\hline 120 & 118 & 113 & 148 & 173 & 130 & 96 & 89 & 45 & 67 & 78 & 47 \\
\hline 150 & 122 & 113 & 153 & 177 & 133 & 99 & 92 & 45 & 68 & 80 & 47 \\
\hline 180 & 125 & 115 & 158 & 183 & 138 & 102 & 94 & 46 & 70 & 82 & 49 \\
\hline 240 & 135 & 122 & - & 197 & - & 111 & 100 & 48 & 74 & 86 & 51 \\
\hline 270 & - & 125 & - & - & - & 116 & - & 49 & 76 & 90 & 52 \\
\hline 300 & - & 130 & - & - & - & - & - & 51 & 80 & 94 & 54 \\
\hline 360 & - & - & - & - & - & - & - & - & - & - & - \\
\hline
\end{tabular}

歩行速度を用い, 地上までの避難所要時間を算定, 5) なお, 避難経路上で, 表-1に示した指標を超えた時 点で避難不可能と判断する.

以上手順で避難の成否を判定した結果を表-4 に示す. ○が安全に避難できた， $\Delta$ が避難困難になったが避難で きた， ×が避難不可能だったことを示している. $\triangle$ 数 值は, 避難困難状態になっていた時間を避難所要時間で 除したものであり，值が大きいほど危険度が増加する. 全てのケースで避難開始の遅れが大きくなるほど，危険 度は増加する結果となった。 地下 1 階は, 流入した水が 地下 1 階の 2 箇所のスロープと 3 箇所の非常階段を通じ, 地下 2 階に流れ込むため, 浸水深が一定の高さとなった. よって, 全てのケースで安全に避難できる結果となった. 地下 2 階は, 避難開始の遅れが 60 秒までなら全てのケ 

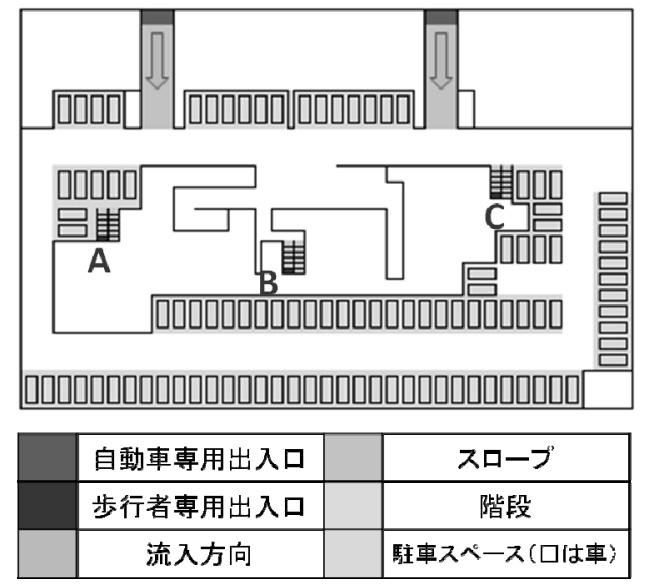

図-11 解析対象とした 1 層構造地下駐車場

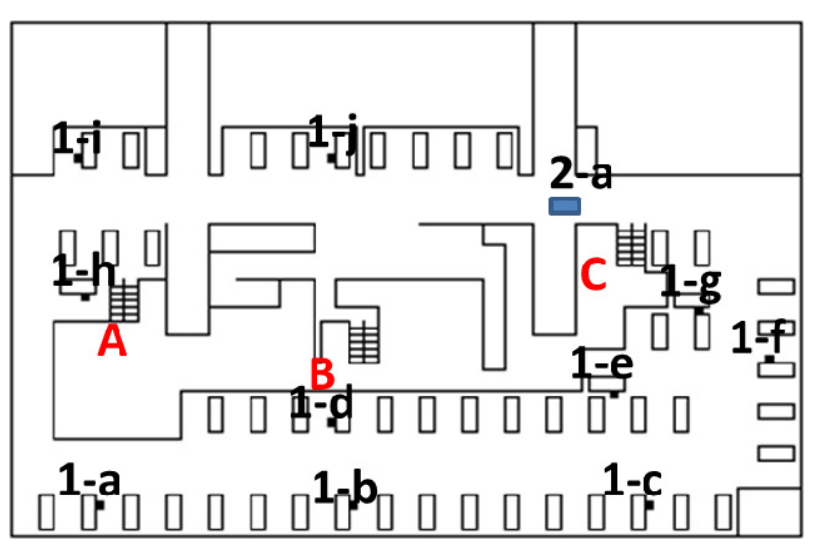

図-12 単層構造の各避難開始位置（シナリオ 1,2 )

一スで安全に避難できる結果となった。避難開始の遅れ が 120 秒では，全てのケースで避難可能だが，地下 2 階 のスロープ付近では避難困難状態となり，スロープ付近 は安全な避難ができない結果となった。 しかし，1-b, 1-d の位置で安全避難できたのは, 地下 1 階から流れ込んで きた水が, 1-b と 1-d の位置にいち早く流れ込むことが浸 水解析の結果から把握でき, 水深が $0.30 \mathrm{~m}$ になる時間が 早いため, 避難開始時刻が他の位置に比べ早いことが原 因である. 脱出限界水深 $0.56 \mathrm{~m}$ を考慮すると， 270 秒以 降は，水深が $0.56 \mathrm{~m}$ 以上なので，車から安全に脱出でき ないこともわかった.

\section{b) 避難所要時間}

避難所要時間を表-5 に示す。避難所要時間は, 脱出所 要時間と移動所要時間の和である．全てのケースで避難 経路長が違うため，避難所要時間に違いがみられた．全 てのケースで避難開始が遅れるほど, 避難所要時間が長 くなる結果となった。これは, 避難開始が遅れるほど水 深が上昇し, 脱出所要時間が長くなることと, 単位幅比 力が大きくなるため, 歩行速度が下がり, 移動所要時間 が長くなることが関係している.

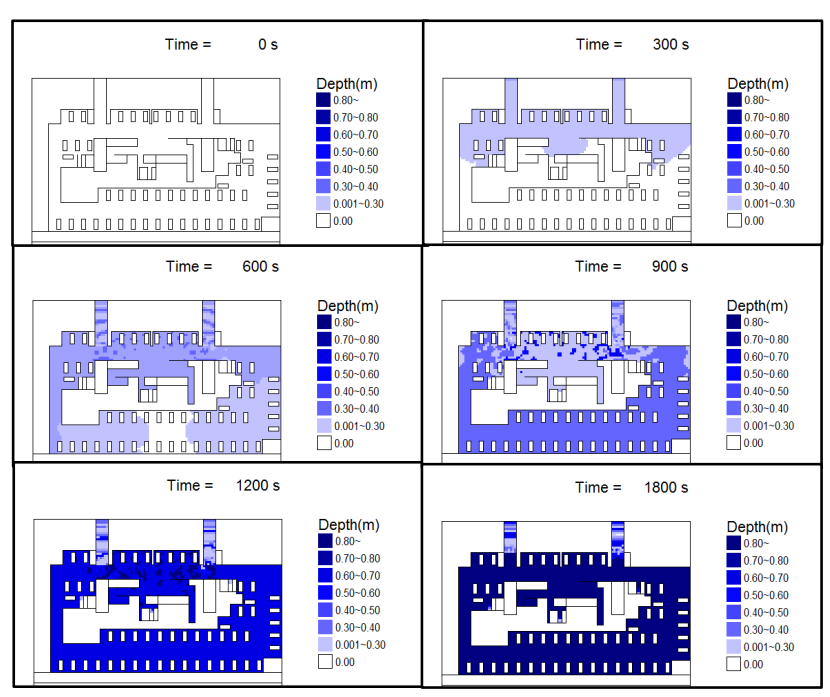

図-13 1 層構造地下駐車場の浸水解析結果

表-6 成人男性の避難の成否 (単層構造)

\begin{tabular}{|c|c|c|c|c|c|c|c|c|c|c|c|}
\hline \multicolumn{12}{|c|}{ 地下1階 } \\
\hline \multirow{2}{*}{$\begin{array}{l}\text { 避離開始 } \\
\text { 幄れ (s) }\end{array}$} & \multicolumn{11}{|c|}{ 各避雜位置からの避䕹の成否 } \\
\hline & 1-a & 1-b & $1-c$ & $1-d$ & $1-\mathrm{e}$ & 1-f & 1-g & 1-h & $1-\mathrm{I}$ & $1-\mathrm{J}$ & $2-a$ \\
\hline 0 & 0 & 0 & 0 & 0 & 0 & 0 & 0 & 0 & 0 & 0 & 0 \\
\hline 60 & 0 & $\Delta 0.11$ & $\Delta 0.03$ & $\Delta 0.12$ & $\Delta 0.34$ & $\Delta 0.02$ & 0 & 0 & 0 & 0 & 0 \\
\hline 120 & $\Delta 0.29$ & $\Delta 0.47$ & $\Delta 0.28$ & $\Delta 0.49$ & $\Delta 0.65$ & $\Delta 0.42$ & $\Delta 0.49$ & 0 & 0 & 0 & 0 \\
\hline 150 & $\Delta 0.64$ & $\Delta 0.68$ & $\Delta 0.43$ & $\Delta 0.68$ & $\Delta 0.68$ & $\Delta 0.46$ & $\Delta 0.50$ & 0 & $\Delta 0.11$ & 0 & 0 \\
\hline 180 & $\Delta 0.86$ & $x$ & $x$ & $x$ & $x$ & $\Delta 0.83$ & $\Delta 0.82$ & $\Delta 0.17$ & $\Delta 0.50$ & 0 & 0 \\
\hline 240 & $x$ & $x$ & $\times$ & $x$ & $\times$ & $x$ & $x$ & $\Delta 0.48$ & $\Delta 0.74$ & $\Delta 0.04$ & $\mathrm{O}$ \\
\hline 270 & $x$ & $x$ & $x$ & $x$ & $\times$ & $\times$ & $\times$ & $\Delta 0.48$ & $\Delta 0.75$ & $\Delta 0.34$ & 0 \\
\hline 300 & $x$ & $x$ & $x$ & $x$ & $x$ & $x$ & $x$ & $\Delta 0.48$ & $\Delta 0.75$ & $\Delta 0.78$ & 0 \\
\hline 360 & $x$ & $x$ & $x$ & $x$ & $x$ & $x$ & $x$ & $x$ & $x$ & $x$ & 0 \\
\hline
\end{tabular}

表-7 成人男性の避難所要時間 (単層構造)

\begin{tabular}{|c|c|c|c|c|c|c|c|c|c|c|c|}
\hline \multicolumn{12}{|c|}{ 地下1陆 } \\
\hline \multirow{2}{*}{ 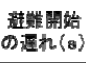 } & \multicolumn{11}{|c|}{ 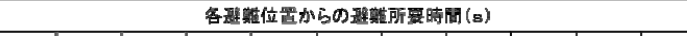 } \\
\hline & $1-a$ & 1-b & $1-c$ & 1-d & 1-e & $1-f$ & $1-8$ & 1-h & $1-i$ & $1-j$ & $2-a$ \\
\hline 0 & 89 & 138 & 117 & 144 & 101 & 79 & 66 & 23 & 44 & 52 & 28 \\
\hline 60 & 93 & 145 & 122 & 151 & 105 & 82 & 68 & 23 & 45 & 53 & 28 \\
\hline 120 & 98 & 154 & 130 & 161 & 111 & 86 & 72 & 24 & 47 & 54 & 29 \\
\hline 150 & 101 & 161 & 136 & 168 & 116 & 89 & 74 & 24 & 47 & 54 & 29 \\
\hline 180 & 106 & - & - & - & - & 94 & 77 & 24 & 48 & 55 & 29 \\
\hline 240 & - & - & - & - & - & - & - & 25 & 51 & 57 & 30 \\
\hline 270 & - & - & - & - & - & - & - & 27 & 54 & 59 & 31 \\
\hline 300 & - & - & - & - & - & - & - & 29 & 58 & 60 & 31 \\
\hline 360 & - & - & - & - & - & - & - & - & - & - & 32 \\
\hline
\end{tabular}

（5）地下駐車場の構造上による危険度の違い

ここでは, 多層構造地下駐車場が単層構造地下駐車場 である場合, どれ程の危険度に違いが出るのか検討する.

\section{a) 多層構造と単層構造との違い}

単層構造地下駐車場にする方法は, 図-8に示した仮想 地下駐車場の地下 2 階に繋がる 3 箇所の非常階段と, 2 箇所のスロープに壁を設け，浸水した水が地下 2 階に流 れない構造とした。作成した仮想地下駐車場を図-11に 示寸. 駐車率は, 多層構造と同じ $50 \%$ と, 地下 1 階に 53 台を配置した. 浸水解析モデル, 単位幅比力の指標, 歩行速度の低下率の指標, 避難状況の想定は, 多層構造 


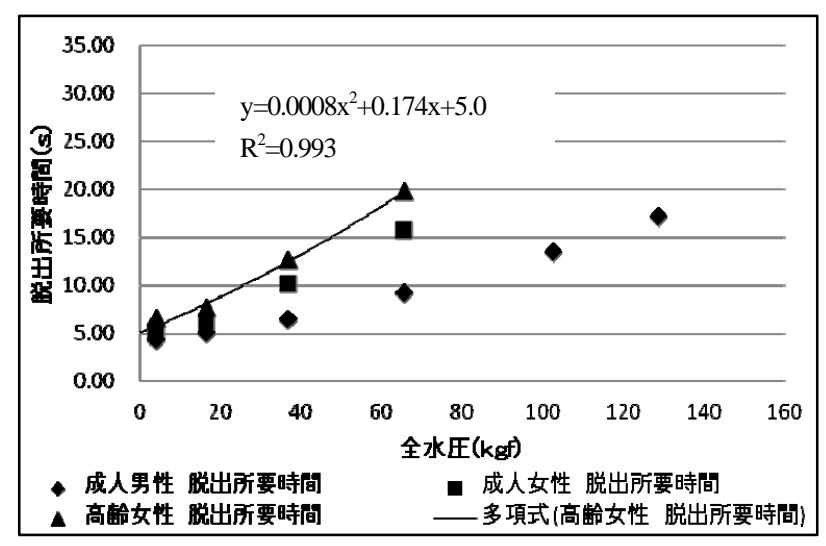

図-14 高齢者女性の脱出所要時間

で行った方法と同じ方法で行った. よって, 避難経路, 避難開始の遅れは, 多層構造の地下 1 階と同じとした. シナリオ 1 , シナリオ 2 の各避難開始位置を図-12に示寸.

\section{b) 浸水解析結果}

浸水解析結果を図-13 に示寸，流入してきた水は，左 右にわかれて広がり続ける結果となり，多層構造地下駐 車場よりも水深上昇速度が速くなる結果となった.

\section{c) 避難解析結果}

(4)の a)で述べた手順で判断した避難の成否を表-6 に 示寸. シナリオ 1 の全てのケースで避難開始遅れが 360 秒になると避難不可能になる結果となった．シナリオ 2 は, 避難開始の遅れが 360 秒でも安全に避難できる結果 となった. これは経路長が一番短いことと, シナリオ 2 の特徵である自動車専用出入口に最も近い位置なので, シナリオ 1 に比べて避難開始時刻が早いことが考えられ る. 避難所要時間を表-7 に示す. 全てのケースで避難開 始が遅れると, 避難所要時間が長くなる結果となった.

d）多層構造と単層構造の危険度の比較

避難所要時間を比較すると, 単層構造の方が避難する までに多くの時間がかかり危険であることが言える。ま た, 単層構造の地下 1 階と多層構造の地下 2 階を避蜼の 成否で比較すると, 多層構造は避難開始の遅れが 60 秒ま でなら安全避難できる結果となったが，単層構造は，避 難開始の遅れが 60 秒でも避難困難状態になる位置があ るので, 単層構造の方が危険であると言える. 単層構造 の方が危険になる理由は，地下駐車場の規模すなわち床 面積が考えられる. 多層構造では, 地下 1 階に浸水した 水は, 地下 2 階に流孔込むが, 地下 1 階にも水は広がる. 単層構造は地下 1 階に浸水した水は溜まっていくので, 水深上昇速度が早いため, 危険であると言える.

\section{（6）成人男性と高齢者女性の危険度の違い}

ここでは，同じ対象地下駐車場で身体能力が低下して いる 65 歳以上の高齢者女性に着目し, 成人男性之高齢者 女性の危険度の違いについて検討する.
表-8 避難の成否の比較（多層構造）

\begin{tabular}{|c|c|c|c|c|c|c|c|c|c|c|c|}
\hline \multicolumn{12}{|c|}{ 地下1階 } \\
\hline \multirow{2}{*}{ 被験者別 } & \multicolumn{11}{|c|}{ 各避難位置からの避難の成否 } \\
\hline & 1-a & 1-b & 1-c & 1-d & 1-e & 1-f & \begin{tabular}{|l|}
$1-\mathrm{g}$ \\
\end{tabular} & 1-h & $1-i$ & $1-\mathrm{J}$ & 2-a \\
\hline 成人男性 & 0 & 0 & 0 & 0 & 0 & 0 & 0 & 0 & 0 & 0 & 0 \\
\hline 高齢女性 & 0 & $\mathrm{O}$ & 0 & 0 & $\mathrm{O}$ & $\mathrm{O}$ & $\mathrm{O}$ & 0 & 0 & $\mathrm{O}$ & 0 \\
\hline \multicolumn{12}{|c|}{ 地下2階 } \\
\hline \multirow{2}{*}{ 被験者別 } & \multicolumn{11}{|c|}{ 各避難位置からの避難の成否 } \\
\hline & 1-a & 1-b & $1-c$ & 1-d & $1-\mathrm{e}$ & 1-f & 1-g & 1-h & $1-\mathrm{I}$ & $1-j$ & $1-k$ \\
\hline 成人男性 & 0 & 0 & 0 & 0 & 0 & 0 & 0 & 0 & 0 & 0 & 0 \\
\hline 高齢女性 & $\Delta 0.26$ & 0 & $\Delta 0.44$ & $\Delta 0.30$ & $\Delta 0.41$ & $\Delta 0.06$ & $\Delta 0.03$ & 0 & 0 & 0 & 0 \\
\hline
\end{tabular}

表-9 避難所要時間の比較 (多層構造)

\begin{tabular}{|c|c|c|c|c|c|c|c|c|c|c|c|}
\hline \multicolumn{12}{|c|}{ 地下1蹧 } \\
\hline \multirow{2}{*}{ 被眏者別 } & \multicolumn{11}{|c|}{ 各避政位道からの避䑾所要時問(8) } \\
\hline & 1-a & 1-b & $1-c$ & 1-d & $1-e$ & 1-f & 18 & 1-h & $1-\mathrm{i}$ & 1-j & $2-a$ \\
\hline 成人男性 & 86 & 137 & 112 & 137 & 95 & 75 & 63 & 21 & 43 & 51 & 23 \\
\hline 高竛女性 & 155 & 248 & 201 & 251 & 172 & 134 & 110 & 35 & 75 & 90 & 38 \\
\hline \multicolumn{12}{|c|}{ 地下2落 } \\
\hline \multirow{2}{*}{ 被睔者別 } & \multicolumn{11}{|c|}{ 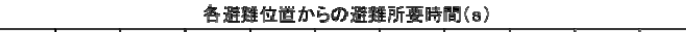 } \\
\hline & 1-a & 1-b & $1-c$ & 1-d & $1-e$ & 1-f & $1-\mathrm{g}$ & 1-h & 1-i & 1-J & $1-k$ \\
\hline 成人男性 & 110 & 106 & 134 & 161 & 117 & 88 & 81 & 43 & 64 & 72 & 43 \\
\hline 高秢女性 & 192 & 189 & 239 & 293 & 209 & 167 & 142 & 69 & 110 & 124 & 73 \\
\hline
\end{tabular}

\section{a）成人男性と高齢者女性との違い}

単位幅比力の指標は，表-1に示した高齢者女性の值を 用い, 浸水時の歩行速度は, 表-2に示した高齢者女性の 計算式で非浸水時歩行速度 $V_{0}$ を通路部 $0.9 \mathrm{~m} / \mathrm{s}$, 階段部 $0.45 \mathrm{~m} / \mathrm{s}$ として計算した. 脱出所要時間は, 図-14に示寸 可搬式ドア模型の結果から算定した值を用いた.

\section{b) 避難解析結果}

多層構造の避難の成否を表-8 に示寸．地下 1 階では, 浸水深が一定の高さであったため, 成人男性と高齢女性 は, 全ての避難開始位置, 避難経路で避難困難状態にな ることはなかった. 地下 2 階では, 成人男性は全てのケ 一スで安全に避難できる結果となったが, 高齢女性は避 難開始の遅れが 0 秒でも避難困難状態になるので, 水没 車に取り残されてからの避難自体が危険であると言え る. 多層構造の避難所要時間を表-9 亿示寸. 高齢女性は 成人男性に比べ避難所要時間が長くなることがわかっ た. これは, 単位幅比力が大きくなる際, 成人男性に比 べて歩行速度の減少率が大きいため, 移動所要時間が長 くなることが考えられる.

\section{4. 安全避難に関する検討}

これまでの結果より, 高齢者女性は水没車に取り残さ れてから脱出し, 地上一避難を開始する状況自体が危険 であることがわかり, 水没車に取り残される前に, 浸水 の危険を察知し, 早めの避難を開始しなければならない. そこで, 地下駐車場内に避難アナウンスを流し, 高齢者 女性が安全に避難をするための検討を行った. 
表-10 避難アナウンスを考慮した高齢者女性の避難の 成否(多層構造)

\begin{tabular}{|c|c|c|c|c|c|c|c|c|c|c|c|}
\hline \multicolumn{12}{|c|}{ 地下1階 } \\
\hline \multirow{2}{*}{$\begin{array}{c}\text { アナウンス } \\
\text { (s) }\end{array}$} & \multicolumn{11}{|c|}{ 各避難位置からの避難の成否 } \\
\hline & $1-a$ & 1-b & $1-\mathrm{c}$ & 1-d & $1-\mathrm{e}$ & 1-f & $1-\mathrm{g}$ & 1-h & $1-\mathrm{i}$ & 1-j & 2-a \\
\hline 0 & 0 & O & 0 & 0 & 0 & 0 & 0 & 0 & 0 & 0 & 0 \\
\hline 300 & $\mathrm{O}$ & O & 0 & 0 & $\mathrm{O}$ & O & O & $\mathrm{O}$ & 0 & 0 & 0 \\
\hline 600 & 0 & 0 & 0 & 0 & 0 & 0 & 0 & 0 & 0 & 0 & 0 \\
\hline 900 & 0 & 0 & 0 & 0 & 0 & 0 & 0 & 0 & 0 & 0 & 0 \\
\hline 1200 & $\mathrm{O}$ & $\mathrm{O}$ & 0 & $\mathrm{O}$ & $\mathrm{O}$ & 0 & O & $\mathrm{O}$ & 0 & 0 & 0 \\
\hline \multicolumn{12}{|c|}{ 地下2階 } \\
\hline \multirow{2}{*}{$\begin{array}{c}\text { アナウンス } \\
\text { (s) }\end{array}$} & \multicolumn{11}{|c|}{ 各避難位置からの避㒕の成否 } \\
\hline & 1-a & 1-b & 1-c & 1-d & $1-e$ & 1-f & $1-\mathrm{g}$ & 1-h & $1-i$ & 1-j & $1-k$ \\
\hline 0 & $\mathrm{O}$ & $\mathrm{O}$ & $\mathrm{O}$ & $\mathrm{O}$ & 0 & 0 & 0 & $\mathrm{O}$ & $\mathrm{O}$ & 0 & 0 \\
\hline 300 & 0 & 0 & O & O & 0 & O & O & $\mathrm{O}$ & 0 & O & 0 \\
\hline 600 & $\mathrm{O}$ & $\mathrm{O}$ & O & 0 & $\mathrm{O}$ & 0 & O & $\mathrm{O}$ & $\mathrm{O}$ & 0 & 0 \\
\hline 900 & 0 & 0 & 0 & 0 & 0 & 0 & 0 & 0 & 0 & 0 & 0 \\
\hline 1200 & $x$ & $x$ & $x$ & $x$ & $x$ & $x$ & $\Delta 0.64$ & $\Delta 0.27$ & $\Delta 0.52$ & $\Delta 0.56$ & $\Delta 0.34$ \\
\hline
\end{tabular}

表-11＼cjkstart避難アナウンスを考慮した高齢者女性の避難の 成否 (単層構造)

\begin{tabular}{|c|c|c|c|c|c|c|c|c|c|c|c|}
\hline \multicolumn{12}{|c|}{ 地下1階 } \\
\hline \multirow{2}{*}{$\begin{array}{c}\text { アナウンス } \\
\text { (s) }\end{array}$} & \multicolumn{11}{|c|}{ 各避竦位置からの避䧸の成否 } \\
\hline & 1-a & 1-b & 1-c & 1-d & 1-e & 1-f & 1-g & 1-h & $1-\mathrm{i}$ & $1-j$ & 2-a \\
\hline 0 & 0 & $\mathrm{O}$ & 0 & 0 & 0 & 0 & 0 & 0 & 0 & 0 & 0 \\
\hline 300 & 0 & 0 & 0 & 0 & 0 & 0 & 0 & 0 & 0 & 0 & 0 \\
\hline 600 & 0 & $\mathrm{O}$ & 0 & 0 & 0 & 0 & 0 & 0 & $\mathrm{O}$ & $\mathrm{O}$ & 0 \\
\hline 900 & $\Delta 0.06$ & $\Delta 0.40$ & $\Delta 0.29$ & $\Delta 0.41$ & $\Delta 0.32$ & $\Delta 0.41$ & $\triangle 0.05$ & 0 & $\mathrm{O}$ & 0 & 0 \\
\hline 1200 & $\times$ & $x$ & $\times$ & $x$ & $x$ & $x$ & $x$ & $x$ & $x$ & $x$ & $x$ \\
\hline
\end{tabular}

\section{a) 避難解析}

避難状況の想定は，地下 1 階に水が流入してから 0 , 300，600，900，1200 秒で避難アナウンスを流し，その 時点でシナリオ 1 , シナリオ 2 と同じ各位置から徒歩で の避難を開始するものとした。

\section{b) 避難解析結果}

多層構造と単層構造の避難の成否を表-10, 表-11 に示 す. 多層構造は, 15 分以内であれば安全に避難でき, 単 層構造は, 10 分以内であれば安全に避難できる結果と なった。

\section{5. おわりに}

本研究では, 浸水した地下駐車場からの避難について 検討した. その結果, 実験結果を用いた避難解析に基づ き，浸水した地下駐車場から避難できるのか，避難開始 の遅れが避難全体にどのような影響を与えるのか, 階層 による危度の違い, 成人男性之高齢者女性による危険度 の違いなどを定量的に検討することができた. 得られた 成果を簡潔にまとめると以下のようになる.

\section{(1) 実験で得られた結果}

成人男性のドアを押す力は, 体重の 20\%〜70\%であり， 脱出限界水深は， $0.56 \mathrm{~m}$ である. 避難の成否を判定する
際に必要な水没した車からの脱出所要時間をドアに作 用する全水圧から算定する式を提示した. 本論文で用い た避難困難度指標, 脱出所要時間, 浸水時の歩行速度の 低下率は, 汇濫解析等で得られる浸水深と流速から算定 可能であるため, 避難計画の策定等の実務に適用可能で ある. また, 内水汇濫や外水汇濫による浸水のみでなく， 高潮や津波の水災害, あるいは水難事故に対する安全性 についても適用可能である.

\section{（2）避難解析で得られた結果}

地下 1 階より地下 2 階の方が危険になることが確認さ れた。特に，地下 2 階で成人男性が水没車に閉じ込めら れた場合，避難開始の遅れが 60 秒になるまでに避難を開 始する必要がある.また, 多層構造と単層構造において, 避難アナウンスを行えば，身体能力が低下している高齢 者女性でも安全に徒歩で避難できることがわかり, 避難 アナウンスは有効な手段であることが確認された.

\section{(3) 今後の課題}

車は，流入してきた水によって浮いて流される状況を 考慮する必要があるため，著者らのグループでは，現在 車の漂流に関する研究を進めており, 今後, その成果を 考慮した検討を行う予定である．また，ここでは，避難 を運転座席に取り残された 1 名を対象としているが，多 人数での避難についても考慮する必要がある.

本研究で対象とした地下駐車場の浸水により，わが国 では人命に係わるような被害は少ないが，2012 年 10 月 29 日にニューヨークを襲ったハリケーン・サンディでは, 高潮汇濫が市街地を浸水させ，地下駐車場に浸水してき た汇濫水により車や人が流されるという被害が発生し， 人命が失われている．東京，名古屋，大阪といったわが 国の大都市は，内水汇濫，外水氾濫，高潮氾濫，津波氾 濫による浸水被害の発生が予測されており，ここで対象 とした地下駐車場を含めた地下空間浸水時の避難に関す る検討および対策の立案に，本研究の成果が役立つと考 えている.

謝辞 : 実験に協力して頂いた京都大学防災研究所の皆様, 浸水解析等について指導して頂いた関西大学大学院工 学研究科総合工学専攻の川中龍児氏, および本実験に参 加していただいた方々に謝意の意を表します。

\section{参考文献}

1) 高橋祐樹，石垣泰輔，馬場康之，戸田圭一：浸水した 大規模地下駐車場からの避難に関する検討，土木学会 地下空間シンポジウム論文・報告集, 第 16 巻, pp.141-146, 2011.

2）大西良純，石垣泰輔，馬場康之，戸田圭一：地下空間 浸水時における避難困難度指標とその適用，土木学会 
水工学論文集, 第 52 巻, pp.841-846, 2008.

3) Asai, Y., Ishigaki, T., Baba, Y. and Toda, K.: Safety Analysis of Evacuation Routes Considering Elderly Persons During Underground Flooding, Journal of Hydroscience and Hydraulics Engineering, Vol.28, No.2, pp.15-21, 2010.

4) 馬場康之, 石垣泰輔, 戸田圭一, 中川一：水没した 自動車からの避難に関寸る実験的研究, 土木学会水工 学論文集, 第 53 巻, pp.853-858, 2009.

5) 馬場康之, 石垣泰輔, 戸田圭一：水没した自動車から の避難の難しさ, 京都大学防災研究所年報, 第 53 号 B-2, pp.553-559, 2010.

6) 馬場康之, 石垣泰輔, 戸田圭一, 中川 一 : 実物大模型 を用いた地下浸水時の避難困難度に関する実験的研究,
土木学会論文集 F2（地下空間研究），Vol.67，No.1, pp.12-27, 2011.

7) 文部科学省 平成 20 年度全国体力 - 運動能力, 運動習 慣等調査結果について, 2009.

8) 高橋祐樹, 石垣泰輔, 馬場康之, 戸田圭一：水没した スライド式ドア車からの避難に関する実験的研究, 土 木学会関西支部年次学術講演会, II-25, 講演概要集, 2011.

9) 武田 誠：高潮の汇濫解析法とその都市域への応用に 関する研究, 京都大学学位論文, 1996.

10) 日本建築防災協会 : 地下空間における浸水ガイドライ ン, G-8-G-10, 2002.

\section{EVACUATION FROM A LARGE-SCALE UNDERGROUND PARKING LOT DURING FLOODING IN URBAN AREA}

\section{Yuki TAKAHASHI, Taisuke ISHIGAKI, Yasuyuki BABA and Keiichi TODA}

When the intensity of precipitation would exceed the design rainfall of drainage system in urban area, some part of flooded water intruded into underground spaces such as underground shopping mall or parking lot. In this paper, the danger of flooding in a large-scale underground parking lot and the safety of evacuation from there are discussed. Flood simulations were made by using a 2D shallow flow model in a model of multilayer underground parking lot. And assessment of safety evacuation was conducted with a criterion of escaping from a submerged real-size car. It is concluded that a short delay of evacuating from inundated place brings a lot of danger to the users stayed on the lower basement. And its danger level also depends on age and gender of person. 